\title{
KINERJA PENGOLAHAN AIR BERSIH DENGAN PROSES FILTRASI DALAM MEREDUKSI KESADAHAN
}

\author{
Oleh : Sri Widyastuti *) \& Antik Sepdian Sari **)
}

\begin{abstract}
Abstrak :
Teknologi filtrasi dengan arah aliran dari atas ke bawah (downflow) banyak diterapkan pada komunitas skala kecil, namun alat ini kurang berfungsi dengan baik saat clogging terjadi perlu pencucian media secara manual.

Penelitian ini bertujuan untuk membandingkan penurunan kecepatan alir filtrat dan efisiensi penurunan kesadahan antara sistem filtrasi upflow dan downflow. Media yang digunakan zeolit karbon aktif setinggi $70 \mathrm{~cm}$. Dalam waktu operasi 6 jam filtrasi diketahui sistem filtrasi upflow kecepatan alirnya stabil sedangkan sistem filtrasi downflow mengalami penurunan $46 \%$. Efisiensi penurunan kesadahan untuk filtrasi dengan sistem upflow sebesar 94,79 \% sedangkan sistem downflow sebesar $94,16 \%$. Dalam hal penurunan kesadahan tidak ada perbedaan yang signifikan antara system filtrasi downflow maupun upflow hal ini telah dibuktikan melalui statistik uji kilat tukey.
\end{abstract}

Kata kunci : Pengolahan air bersih, up flow dan down flow, filtrasi

\section{PENDAHULUAN \\ Latar Belakang}

Salah satu sumber air yang masih banyak digunakan oleh masyarakat adalah air sumur gali, akan tetapi tidak semuanya memenuhi syarat kesehatan. Faktor-faktor yang dapat mempengaruhi rendahnya kualitas air sumur gali antara lain : musim, konstruksi, jenis dan kemiringan tanah, jarak dari sumber pengotoran dan perilaku makhluk hidup disekitarnya. Selama menjalani daur hidrologi air selalu menyerap zat-zat yang menyebabkan air itu tidak lagi murni. Oleh karena itu, pada hakekatnya tidak ada air yang betul-betul murni. Zat-zat yang diserap oleh air alam dapat diklasifikasikan sebagai padatan terlarut, gas terlarut dan padatan tersuspensi. Pada umumnya, jenis zat pengotor yang terkandung dalam air bergantung pada jenis bahan yang berkontak dengan air itu, sedangkan banyaknya zat pengotor bergantung pada waktu kontaknya.

Salah satu teknik pengolahan air yang sangat cocok untuk memenuhi kebutuhan akan air bersih pada komunitas skala kecil atau skala rumah tangga adalah system filtrasi. Teknologi filtrasi yang banyak diterapkan di Indonesia biasanya adalah filtrasi konvensional dengan arah aliran dari atas ke bawah ( Down Flow ), sehingga jika kekeruhan air baku naik, terutama pada waktu hujan, maka sering terjadi penyumbatan pada saringan pasir, sehingga perlu dilakukan pencucian secara manual. Hal inilah yang sering menyebabkan saringan pasir lambat yang telah dibangun kurang berfungsi dengan baik, terutama pada musim hujan masyarakat umumnya malas melakukan pemeliharaan akibatnya alat tidak digunakan lagi dan mereka kembali memanfaatkan air kotor.

\section{Perumusan Masalah}

1. Apakah ada perbedaan penurunan kecepatan alir filtrat yang dihasilkan antara arah aliran down flow dan up flow.

2. Berapa persen penurunan kadar kesadahan $\left(\mathrm{CaCO}_{3}\right)$ dari filtrat yang dihasilkan baik dengan arah aliran down flow dan up flow.

\section{Tujuan Penelitian}

1. Untuk mengetahui berapa persen penurunan kesadahan $\left(\mathrm{CaCO}_{3}\right)$ dari pengolahan system filtrasi dengan arah aliran down flow dan up flow.

2. Untuk mengetahui penurunan kecepatan alir filtrat antara system filtrasi upflow dan downflow sehingga dapat diketahui sistem manakah yang lebih efektif untuk diterapkan di masyarakat.

\section{Manfaat Penelitian}

1. Mendapatkan suatu alternatif teknologi yang murah, sederhana, dan mudah pengoperasiaannya untuk menurunkan kadar kesadahan pada air sumur.

2. Memberikan data informasi tentang kemampuan filtrasi dalam menurunkan kadar kesadahan dengan menggunakan proses filtrasi dualmedia yaitu zeolit dan karbon aktif.

3. Memberikan data informasi tentang kemampuan filtrasi antara system up flow dan down flow meliputi keuntungan dan kelemahan masing-masing. 
4. Sebagai bahan kajian dan referensi kepada penelitian berikutnya untuk dapat mengembangkan hasil yang diperoleh dari penelitian ini dan mencoba berbagai variasi percobaan sehingga nantinya akan memperoleh data yang lebih lengkap tentang kemampuan teknologi fitrasi dual media antara system up flow dan down flow.

\section{KAJIAN PUSTAKA \\ Air Bersih}

Air bersih adalah salah satu jenis sumber daya berbasis air yang bermutu baik dan biasa dimanfaatkan oleh manusia untuk dikonsumsi atau dalam melakukan aktivitas mereka sehari - hari termasuk diantaranya sanitasi. Macam - macam sumber air bersih diantaranya :

1. Air laut

Air laut mempunyai sifat asin karena mengandung garam $\mathrm{NaCl} 3 \%$.

2. Air Atmosfer

Air atmosfer jatuh ke bumi dalam bentuk air hujan. Air hujan mengandung banyak kotoran. Selain itu air hujan mempunyai sifat agresif terutama terhadap pipa-pipa penyalur maupun bak-bak reservoir, sehingga hal ini akan mempercepat terjadinya korosi atau karatan. Air hujan mempunyai sifat sadah, sehingga akan boros terhadap pemakaian sabun.

3. Air Permukaan

Air permukaan berasal dari aliran langsung air hujan di permukaan bumi.

4. Air tanah

Air tanah adalah air yang berada di bawah permukaan tanah di dalam zone jenuh dimana tekanan hidrostatiknya sama atau lebih besar dari tekanan atmosfer. Air tanah terbagi atas air tanah dangkal dan air tanah dalam. Air tanah dangkal, terjadi karena adanya daya proses peresapan air dari permukaan tanah. Air dangkal ini ditinjau dari segi kualitas baik, segi kuantitas kurang dan tergantung pada musim. Air tanah dalam, terdapat setelah lapis rapat air yang pertama. Pengambilan air tanah dalam, tak semudah pada air tanah dangkal karena harus digunakan bor dan memasukkan pipa kedalamannya sehingga dalam suatu kedalaman biasanya antara $100-300 \mathrm{~m}^{2}$.

5. Mata air

Mata air yaitu air tanah yang keluar dengan sendirinya ke permukaan tanah dalam hampir tidak terpengaruh oleh musim dan kualitas atau kuantitasnya sama dengan air dalam.

\section{FILTRASI \\ Pengertian Filtrasi}

Filtrasi adalah Proses pemisahan solid-liquid dengan cara melewatkan liquid melalui media berpori atau bahan - bahan berpori untuk menyisihkan atau menghilangkan sebanyak - banyaknya butiran - butiran halus zat padat tersuspensi dari liquida. Faktor yang mempengaruhi efisiensi penyaringan ada 4 ( empat) yaitu :

1. Kualitas air baku, semakin baik kualitas air baku yang diolah maka akan baik pula hasil penyaringan yang diperoleh.

2. Suhu, Suhu yang baik yaitu antara 20-30 ${ }^{\circ} \mathrm{C}$, temperatur akan mempengaruhi kecepatan reaksi-reaksi kimia.

3. Kecepatan Penyaringan, Pemisahan bahan-bahan tersuspensi dengan penyaringan tidak dipengaruhi oleh kecepatan penyaringan. Berbagai hasil penelitian menyatakan bahwa kecepatan penyaringan tidak mempengaruhi terhadap kualitas effluent. Kecepatan penyaringan lebih banyak terhadap masa operasi saringan.

4. Diameter butiran, secara umum kualitas effluent yang dihasilkan akan lebih baik bila lapisan saringan pasir terdiri dari butiran-butiran halus. Jika diameter butiran yang di gunakan kecil maka yang terbentuk juga kecil. Hal ini akan meningkatkan efisiensi penyaringan.

Tersumbatnya media filter ditandai oleh :

1. Penurunan kapasitas produksi atau kecepatan alir filtrat.

2. Peningkatan kehilangan energi ( headloss ) yang diikuti oleh kenaikan muka air diatas media.

3. Penurunan kualitas air produksi.

Fungsi Alat filtrasi :

1. Proses pemisahan zat padat atau zat padat halus, baik yang tersuspensi maupun koloid dari fluida dengan menggunakan media berpori

2. Removal terhadap zat padat, kandungan bakteri, menghilangkan warna, rasa, bau, besi dan mangan.

\section{Bagian Alat Filtrasi :}

1. Bak filter

Bak tempat proses filtrasi berlangsungJumlah dan ukuran bak tergantung debit pengolahan (minimum dua bak).

2. Media filter

Bahan berbutir/ granular sebagai media penyaringan, dimana air akan melewati pori-pori diantara butiran tersebut Macam media: singlemedia, dualmedia, multime- 
dia. Susunan berdasarkan ukuran: seragam, gradasi, tercampur.

3. Sistem underdrain

Merupakan sistem pengaliran air yang telah melewati proses filtrasi terletak di bawah media filter terdiri dari: manifold, lateral dan orifice.

\section{Operasi Filtrasi}

1. Selama proses filtrasi berlangsung, partikel yang terbawa air akan tersaring di media filter

2. Partikel-partikel ini lama kelamaan akan menyumbat pori-pori media sehingga terjadi clogging (penyumbatan)

3. Clogging akan meningkatkan headloss aliran air di media.

4. Peningkatan headloss dapat dilihat dari meningkatnya permukaan air di atas media atau menurunnya debit filtrasi

5. Proses filtrasi harus dihentikan yakni :

a. Bila konsentrasi suspended solid mulai meningkat

b. Bila headloss yang terjadi pada medium filter bed sudah melampaui batas yang diperkenankan.

c. Jika terjadi penyumbatan pori - pori media maka harus dilakukan pencucian ( backwash ). Adapun operasi filtrasi dan pencucian ( backwash ) dapat dilihat pada gambar 1 di bawah ini :

\section{Jenis Operasi Filtrasi}

Dapat digolongkan berdasarkan :

\section{Tipe Operasi}

a. Filtrasi semi continues, dimana tahap operasi penyaringan dan pencucian berlangsung secara bergantian.

b. Filtrasi continues, dimana tahap penyaringan dan pencucian berlangsung secara simultan.

2. Arah Aliran
a. Upflow
b. Downflow

3. Metode Kendali Aliran

a. Gaya gravitasi

b. Gaya tekan (pressure filter)

4. Jenis Media

a. Single media, yaitu dengan satu jenis media pasir.

b. Dual media, yaitu dengan dua jenis media.

c. Multi media, yaitu dengan beberapa media.

\section{Mekanisme Filtrasi}

1. Mechanical straining

Mechanical straining adalah proses penyaringan partikel suspended matter yang terlalu besar untuk lolos dari lubang diantara butiran pasir.

2. Sedimentasi

Sedimentasi adalah proses pengendapan partikel tersuspensi yang lebih halus ukurannya daripada lubang pori pada permukaan butiran.

3. Adsorbsi

Adsorbsi adalah proses penghilangan partikel koloidal yang berasal dari bahan organik maupun non organik yang tidak terendapkan. Beberapa sifat yang harus dipenuhi oleh zat penyerap yaitu:

a. Mempunyai luas permukaan yang besar.

b. Berpori-pori

c. Aktif dan murni

d. Tidak bereaksi dengan zat yang akan diserap.

Adapun faktor yang mempengaruhi kapasitas adsorbsi yaitu:

a. Luas permukaan adsorben.

Semakin luas permukaan adsorben, semakin banyak adsorbat yang dapat diserap, sehingga proses adsorbsi dapat semakin efektif. Semakin kecil ukuran diameter partikel maka semakin luas permukaan adsorben.

b. Ukuran partikel

Makin kecil ukuran partikel yang digunakan maka semakin besar kecepatan adsorbsinya. Ukuran diameter dalam bentuk butir adalah lebih dari $0.1 \mathrm{~mm}$, sedangkan ukuran diameter dalam bentuk serbuk adalah 200 mesh (Tchobanoglous, 1991).

c. Waktu kontak

Waktu kontak yang lebih lama memungkinkan proses difusi dan penempelan molekul adsorbat berlangsung lebih baik. Konsentrasi zatzat organik akan turun apabila waktu kontaknya cukup dan waktu kontak berkisar 10 - 15 menit (Reynolds, 1982).

d. Distribusi ukuran pori

Distribusi pori akan mempengaruhi distribusi ukuran molekul adsorbat yang masuk kedalam partikel adsorben.

4. Interception

Interception terjadi bila zat padat bergerak langsung menuju dan membentur media filter sebagai akibatnya zat padat tersuspensi melekat pada media filter

5. Aktivitas kimia

Dalam filter ada aktivitas kimia karena bereaksinya beberapa senyawa kimia dengan oksigen ataupun dengan bikarbonat. 
6. Aktivitas biologis

Aktivitas mikroorganisme yang hidup didalam filter secara alamiah hidup didalam air baku dan bila melalui filter dapat berkembang biak dalam filter. Berikut ilustrasi dari beberapa mekanisme filrasi dapat dilihat pada gambar 1 di bawah ini :

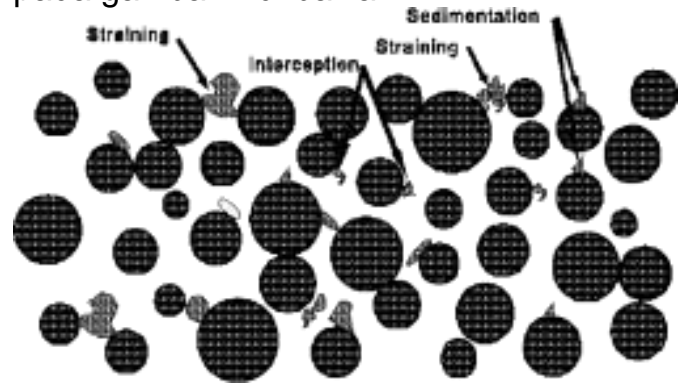

Gambar 1 : Pemisahan zat padat pada Filtrasi

\section{Tipe Filtrasi}

Berdasarkan kapasitas produksi air yang terolah, filter dibagi menjadi 2 type, yaitu:

1. Saringan Pasir Cepat (Rapid sand filter )
2. Saringan Pasir Lambat (Slow Sand Filter) Saringan pasir lambat merupakan proses filtrasi lambat dengan media pasir atau multimedia untuk proses pengolahan air permukaan yang tidak melalui unit - unit koagulasi, flokulasi dan sedimentasi. Dalam proses kerjanya saringan pasir lambat tidak membutuhkan penambahan bahan kimia, tetapi proses akan lebih efisien jika kecepatan alir konstan dan lambat untuk mendukung aktifitas biologi. Proses yang terjadi adalah proses fisikbiologis dan biokimia dengan bantuan mikroorganisme yang terbentuk pada media filtrasi. Teknologi saringan pasir lambat ini telah digunakan secara luas di Eropa sejak tahun 1800, kaitannya dalam mendegradasi mikroorganisme yang sangat efisien. Tabel 1 di bawah ini menunjukkan beberapa mikroorganisme yang mampu terdegradasi oleh saringan pasir lambat sebagai berikut :

Tabel 1 Degradasi mikroorganisme oleh saringan pasir lambat

\begin{tabular}{|c|c|c|c|c|}
\hline Reference & Organism & Filtration rate $(\mathrm{m} / \mathrm{h})$ & Temperature $\left({ }^{\circ} \mathrm{C}\right)$ & Removal percentage \\
\hline Poynter and Slade (1977) & Poliovirus & 0.2 & 16 to 18 & 99.997 average \\
\hline Poynter and Slade (1977) & Poliovirus & 0.4 & 16 to 18 & 99.865 average \\
\hline Poynter and Slade (1977) & Poliovirus & 0.2 & 5 to 8 & 99.68 average \\
\hline Poynter and Slade (1977) & Poliovirus & 0.5 & 5 to 8 & 98.25 average \\
\hline Bellamy et al. (1985b) & Total coliform bacteria & 0.12 & 17 & 97 average \\
\hline Bellamy et al. (1985b) & Total coliform bacteria & 0.12 & 5 & 87 average \\
\hline Bellamy et al. (1985a) & Giardia & 0.12 & 5 to 15 & 99.994 average \\
\hline Bellamy et al. (1985a) & Giardia & 0.4 & 5 to 15 & 99.981 average \\
\hline Bellamy et al. (1985b) & Giardia & 0.12 & 17 & $>99.93$ to $>99.99$ \\
\hline Bellamy et al. (1985b) & Giardia & 0.12 & 5 & $>99.92$ to $>99.99$ \\
\hline Pyper (1985) & Giardia & 0.08 & 0.5 & 93.7 \\
\hline Pyper (1985) & Giardia & 0.08 & 0.5 to 0.75 & 99.36 to 99.91 \\
\hline Pyper (1985) & Giardia & 0.08 & 7.5 to 21 & 99.98 to 99.99 \\
\hline Ghosh et al. (1989) & Giardia & 0.3 & 4.5 to 16.5 & $>99.99$ \\
\hline Ghosh et al. (1989) & Giardia & 0.4 & 4.5 to 16.5 & 99.83 to 99.99 \\
\hline Ghosh et al. (1989) & Cryptosporidium oocysts & 0.15 to 0.40 & 4.5 to 16.5 & $>99.99$ \\
\hline Hall et al. (1994) & Cryptosporidium oocysts & 0.2 & Not stated & 99.8 to 99.99 \\
\hline EES and TWU (1996 $\left.{ }^{a}\right)$ & Cryptosporidium oocysts & 0.29 & 12 to 14 & $>99.99$ \\
\hline
\end{tabular}

(G.S. Logsdon, et all, 2002)

\section{Keuntungan dari saringan pasir lambat:}

1. Efektif

Saringan pasir lambat merupakan instansi pengolahan yang dapat berdiri sendiri dan sekaligus dapat memperbaiki kualitas secara fisik, kimia, biologis, bahkan dapat menghilangkan sama sekali bakteri pathogen tetapi dengan ketentuan operasi dan pemiliharaan filter dilakukan secara benar dan baik.

2. Murah

Saringan pasir lambat tidak memerlukan energi dan bahan kimia serta pembuatan alat tidak memerlukan biaya besar, maka biaya konstruksinya akan lebih murah dari biaya konstruksi saringan pasir cepat.

3. Sederhana

Operasi dan pemiliharaanya murah, tidak memerlukan tenaga khusus yang terdidik dan terampil khusus berkaitan dengan pembersihan.

Kerugian dari saringan pasir lambat:

1. Sangat sensitif dengan variasi $\mathrm{pH}$ air baku

2. Sangat peka terhadap kekeruhan.

3. Waktu pengendapan air baku cukup lama sehingga proses filtrasi juga berlangsung lama 
4. Memerlukan lahan yang cukup luas selain untuk filtrasi itu sendiri tetapi juga untuk pengendap yang digunakan. Adapun kriteria - kriteria saringan pasir lambat ditunjukkan dalam tabel 3 di bawah ini :

Tabel 2. Kriteria Saringan pasir Lambat

\begin{tabular}{lll}
\hline No. & Kriteria & Ukuran yang direkomendasikan \\
\hline 1. & kecepatan alir & $2-5 \mathrm{~m} 3 / \mathrm{m} 2$ hari \\
2. & Ukuran bak & $2000 \mathrm{~m} 2$ \\
3. & Ketebalan media & Pasir $1 \mathrm{~m} ;$ gravel $0.3 \mathrm{~m}$ \\
4. & Koefisien keseragaman & $2-2.5$ \\
5. & Headloss & $1 \mathrm{~m}$ \\
6. & Metode pencucian & Mencuci/ mengeruk lapisan atas dan mengganti \\
& dengan pasir baru \\
7. & Penyisihan bakteri & $99.99 \%$ \\
8. & Diameter media & $0.5-1.5 \mathrm{~mm}$ \\
& & \\
9. & Treatment dg koagulasi & Tidak perlu \\
\hline
\end{tabular}

(Joko Sutrisno,2006)

Adapun gambar saringan pasir lambat dan bagian - bagiannya dapat dilihat pada gambar 2 di bawah ini :

\section{Slow Sand Filter}

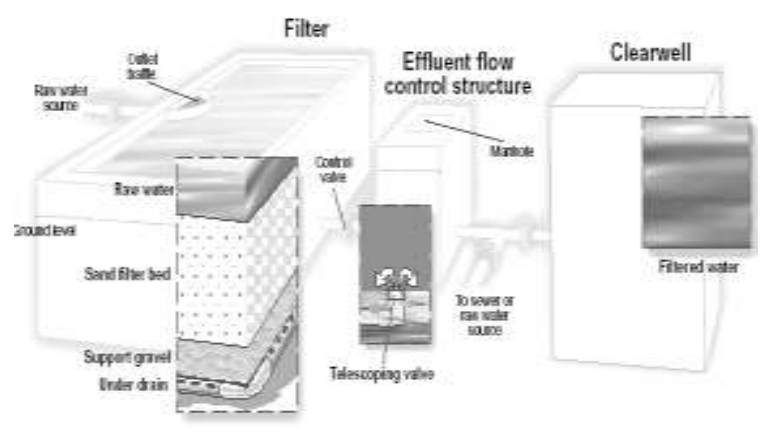

Gambar 2. Saringan pasir lambat

\section{MEDIA FILTRASI \\ Zeolit}

Zeolit merupakan suatu mineral yang dihasilkan dari proses hidrothermal pada batuan beku basa, secara umum zeolit mampu menyerap, menukar ion dan menjadi katalis. Sifat zeolit sebagai adsorben dan penyaring molekul, dimungkinkan karena struktur zeolit yang berongga, sehingga zeolit mampu menyerap sejumlah besar molekul yang berukuran lebih kecil atau sesuai dengan ukuran rongganya. Selain itu kristal zeolit yang telah terdehidrasi merupakan adsorben yang selektif dan mempunyai efektivitas adsorpsi yang tinggi.

Sedangkan sifat zeolit sebagai penukar ion karena adanya kation logam alkali dan alkali tanah. Kation tersebut dapat bergerak bebas didalam rongga dan dapat dipertukarkan dengan kation logam lain dengan jumlah yang sama. Akibat struktur zeolit berongga, anion atau molekul berukuran lebih kecil atau sama dengan rongga dapat masuk dan terjebak. Berikut adalah media zeolit dapat lihat pada gambar 5 di bawah ini :

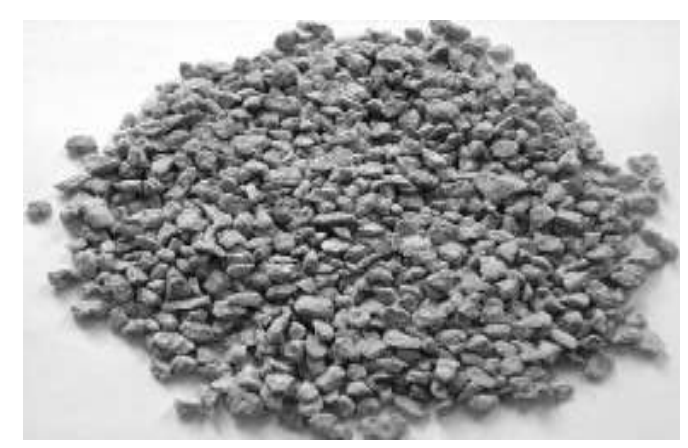

Gambar 3 : zeolit

Zeolit berbentuk kristal aluminosilikat terhidrasi yang mengandung muatan positif dari ion-ion logam alkali dan alkali tanah dalam kerangka kristal tiga dimensi (Hay, 1966), dengan setiap oksigen membatasi antara dua tetrahedral. Berikut ilustrasi dari rangka zeolit dapat dilihat pada gambar 6 di bawah ini :

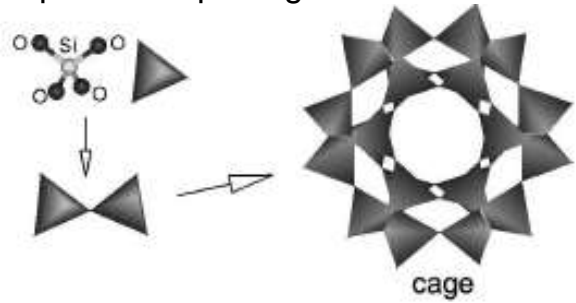

Gambar 4 : Rangka zeolit yang terbentuk dari 4 atom $\mathrm{O}$ dan 1 atom $\mathrm{Si}$.

\section{Tahapan Pengolahan Zeolit}

1) Tahapan preparasi

Tahap ini berupa pengecilan ukuran dan pengayakan. 
2) Tahapan aktivasi

Aktivasi zeolit dapat dilakukan dengan cara pemanasan atau penambahan pereaksi kimia baik asam maupun basa:

a. Aktivasi pemanasan, dilakukan zeolit dalam pengering putar menggunakan bahan umpan yang mempunyai kadar air sekitar $40 \%$, dengan suhu tetap $230{ }^{\circ} \mathrm{C}$ dan waktu pemanasan selama tiga jam.

b. Penambahan pereaksi kimia, dilakukan di dalam bak pengaktifan dengan $\mathrm{NaOH}$ dan $\mathrm{H}_{2} \mathrm{SO}_{4}$, dimaksudkan untuk memperoleh temperatur yang dibutuhkan dalam aktivasi. Zeolit yang telah diaktivasi perlu dikeringkan terlebih dahulu, pengeringan ini dapat dilakukan dengan cara menjemurnya di bawah sinar matahari.

\section{Karbon Aktif}

Karbon berpori atau lebih dikenal dengan nama karbon aktif, digunakan sebagai adsorben untuk menghilangkan warna, pengolahan limbah, pemurnian air. Karbon aktif akan membentuk amorf yang sebagian besar terdiri dari karbon bebas dan memiliki permukaan dalam yang berongga, warna hitam, tidak berbau, tidak berasa, dan mempunyai daya serap yang jauh lebih besar dibandingkan dengan karbon yang belum menjalani proses aktivasi. Adapun bentuk karbon aktif dapat dilihat pada gambar 7 di bawah ini:

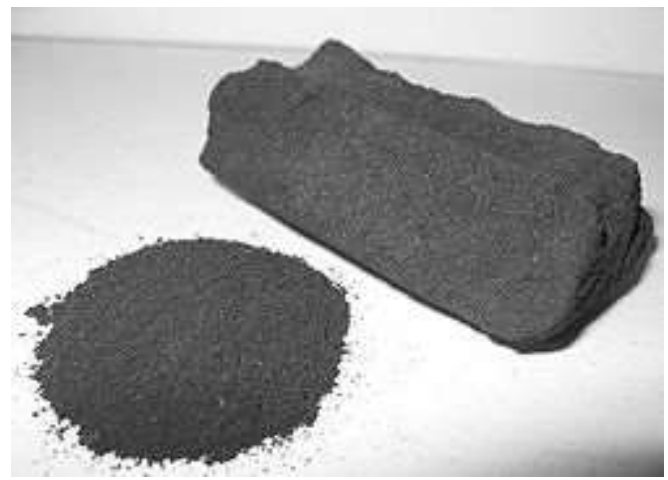

Gambar 5 : karbon aktif

Luas permukaan karbon aktif berkisar antara $300-3500 \mathrm{~m}^{2} / \mathrm{gram}$ dan ini berhubungan dengan struktur pori internal yang menyebabkan karbon aktif mempunyai sifat sebagai adsorben. Karbon aktif dapat mengadsorpsi gas dan senyawa-senyawa kimia tertentu atau sifat adsorpsinya selektif, tergantung pada besar atau volume pori-pori dan luas permukaan. Dalam hal ini, ada beberapa faktor yang mempengaruhi daya serap adsorpsi, yaitu : a. Sifat Adsorben
Struktur pori berhubungan dengan luas permukaan, semakin kecil pori-pori arang aktif, mengakibatkan luas permukaan semakin besar. Dengan demikian kecepatan adsorpsi bertambah. Untuk meningkatkan kecepatan adsorpsi, dianjurkan agar menggunakan karbon aktif yang telah dihaluskan. Jumlah atau dosis karbon aktif yang digunakan, juga diperhatikan.

b. Sifat Serapan

Adsorpsi akan bertambah besar sesuai dengan bertambahnya ukuran molekul serapan dari sturktur yang sama, seperti dalam deret homolog. Adsorsi juga dipengaruhi oleh gugus fungsi, posisi gugus fungsi, ikatan rangkap, struktur rantai dari senyawa serapan.

c. Temperatur

Dalam pemakaian karbon aktif dianjurkan untuk menyelidiki. temperatur pada saat berlangsungnya proses. Karena tidak ada peraturan umum yang biasanya diberikan mengenai temperatur yang digunakan dalam adsorpsi. Faktor yang mempengaruhi temperatur proses adsoprsi adalah viskositas dan stabilitas thermal senyawa serapan. Jika pemanasan tidak mempengaruhi sifat-sifat senyawa serapan, seperti terjadi perubahan warna mau dekomposisi, maka perlakuan dilakukan pada titik didihnya. Untuk senyawa volatil, adsorpsi dilakukan pada temperatur kamar atau bila memungkinkan pada temperatur yang lebih kecil.

d. $\mathrm{pH}$ (Derajat Keasaman)

Untuk asam-asam organik adsorpsi akan meningkat bila $\mathrm{pH}$ diturunkan, yaitu dengan penambahan asam-asam mineral. Hal ini disebabkan karena kemampuan asam mineral untuk mengurangi ionisasi asam organik tersebut. Sebaliknya bila pH asam organik dinaikkan yaitu dengan menambahkan alkali, adsorpsi akan berkurang sebagai akibat terbentuknya garam.

e. Waktu Kontak

Bila karbon aktif ditambahkan dalam suatu cairan, dibutuhkan waktu untuk mencapai kesetimbangan. Waktu yang dibutuhkan berbanding terbalik dengan jumlah yang digunakan. Waktu yang dibutuhkan ditentukan oleh dosis karbon aktif, pengadukan juga mempengaruhi waktu kontak. Pengadukan dimaksudkan untuk memberi kesempatan pada partikel arang aktif untuk bersinggungan dengan senyawa serapan. Untuk larutan yang mempunyai viskositas tinggi, dibutuhkan waktu singgung yang lebih lama. Penggunaan 
bubuk karbon aktif mempunyai kelebihan sebagai berikut :

a. Sangat ekonomis karena ukuran butir yang kecil dan luas permukaan kontak persatuan berat sangat besar.

b. Kontak menjadi sangat baik dengan mengadakan pengadukan cepat dan merata.

c. Tidak memerlukan tambahan alat lagi karena karbon akan mengendap bersama Lumpur yang terbentuk.

d. Kemungkinan mikroorganisme sangat kecil.

\section{Kajian Parameter Kesadahan}

Kesadahan air adalah kandungan mineral-mineral tertentu di dalam air, umumnya ion $\mathrm{Ca}$ dan $\mathrm{Mg}$ dalam garam karbonat. Air sadah adalah air yang memiliki kadar mineral tinggi, sedangkan air lunak adalah air dengan kadar mineral yang rendah. Kesadahan air dapat dibedakan atas dua macam, yaitu kesadahan sementara dan kesadahan tetap. Kesadahan sementara disebabkan oleh garam-garam karbonat $\left(\mathrm{CO}_{3}{ }^{2-}\right)$ dan bikarbonat $\left(\mathrm{HCO}^{3-}\right)$ dari Kalsium $(\mathrm{Ca})$ dan Magnesium (Mg). Kesadahan tetap disebabkan oleh adanya garam-garam klorida $\left(\mathrm{Cl}^{-}\right)$ dan sulfat $\left(\mathrm{SO}_{4}{ }^{2-}\right)$ dari $\mathrm{Ca}$ dan $\mathrm{Mg}$. Kesadahan karena garam-garam tersebut bersifat tetap dan sukar dihilangkan. Berdasarkan tingkat kesadahannya, air dapat dibedakan atas beberapa macam. Tabel 4 di bawah ini menunjukkan tingkatan derajat kesadahan dalam satuan ppm untuk masing - masing kategori air sadah.

Tabel 3. Derajat Kesadahan

\begin{tabular}{lll}
\hline Derajat Kesadahan & $\mathrm{CaCO}_{3}(\mathbf{p p m})$ & lon $\mathrm{Ca}^{2+}$ \\
\hline Lunak & $<50$ & $<2.9$ \\
Agak sadah & $50-100$ & $2.9-5.9$ \\
Sadah & $100-200$ & $5.9-11.9$ \\
Sangat sadah & $>200$ & $>11.9$ \\
\hline
\end{tabular}

(BAPEDALDA PROP. JATIM, 2007 )

Di alam keberadaan mineral-mineral ini umumnya akibat kontak antara air dengan batuan-batuan yang mengandung mineral $\mathrm{Ca}$ dan $\mathrm{Mg}$ oleh karena itu air sadah banyak di jumpai pada daerah pegunungan kapur. Sedangkan sumber pencemarnya bisa juga berasal dari kegiatan industri soda, pembuatan gips, dan semen.

Dampaknya terhadap lingkungan dan manusia diantaranya Air dengan kesadahan tinggi akan mempengaruhi biota air khususnya ikan dan tumbuh-tumbuhan. Pada ikan, air dengan kesadahan tinggi dapat mengganggu fungsi ginjal dan menghambat pertumbuhan. Sedangkan pada tanaman akan mempengaruhi transfer hara dan hasil sekresi melalui membran, serta dapat mempengaruhi kesuburan. Hal ini disebabkan oleh daya adaptasi yang berbeda pada setiap ikan atau tanaman. Air sadah dapat menyebabkan pengendapan mineral yang menyumbat saluran pipa dan keran. Menimbulkan kerak pada ketel uap sehingga air lama mendidih, dan menyebabkan pemborosan bahan bakar. Menyebabkan pemborosan penggunaan sabun.

Metode yang digunakan dalam penentuan kesadahan total adalah titrimetri EDTA dengan prinsip Garam dinatrium etilen diamin tetra asetat (EDTA) akan bereaksi dengan kation logam tertentu membentuk senyawa kompleks kelat yang larut. Pada $\mathrm{pH}$ $10,0 \pm 0,1$, ion-ion kalsium dan magnesium dalam contoh uji akan bereaksi dengan indikator Eriochrome Black T (EBT), dan membentuk larutan berwarna merah keunguan. Jika $\mathrm{Na}_{2}$ EDTA ditambahkan sebagai titran, maka ion-ion kalsium dan magnesium akan membentuk senyawa kompleks, molekulindikator terlepas kembali, dan pada titik akhir titrasi larutan akan berubah warna dari merah keunguan menjadi biru. Dari cara ini akan didapat kesadahan total ( $\mathrm{Ca}+$ $\mathrm{Mg}$ ).

Kalsium dapat ditentukan secara langsung dengan EDTA bila pH contoh uji dibuat cukup tinggi (12-13), sehingga magnesium akan mengendap sebagai magnesium hidroksida dan pada titik akhir titrasi indikator Eriochrome Black T (EBT) hanya akan bereaksi dengan kalsium saja membentuk larutan berwarna biru. Dari cara ini akan didapat kadar kalsium dalam air ( $\mathrm{Ca}$ ). Dari kedua cara tersebut dapat dihitung kadar magnesium dengan cara mengurangkan hasil kesadahan total dengan kadar kalsium yang diperoleh, yang dihitung sebagai $\mathrm{CaCO}_{3}$.

\section{METODE PENELITIAN \\ Rancangan Penelitian}

Penelitian yang dilakukan adalah penelitian eksperimen yaitu membandingkan kecepatan alir filtrat antara sistem filtrasi upflow dan downflow guna mengetahui sistem filtrasi mana yang mempunyai waktu operasi 
lebih lama dengan memperhatikan efisiensi penurunan parameter kesadahan. Adapun rancangan penelitiannya seperti yang ditunjukkan pada gambar 6 sebagai berikut :

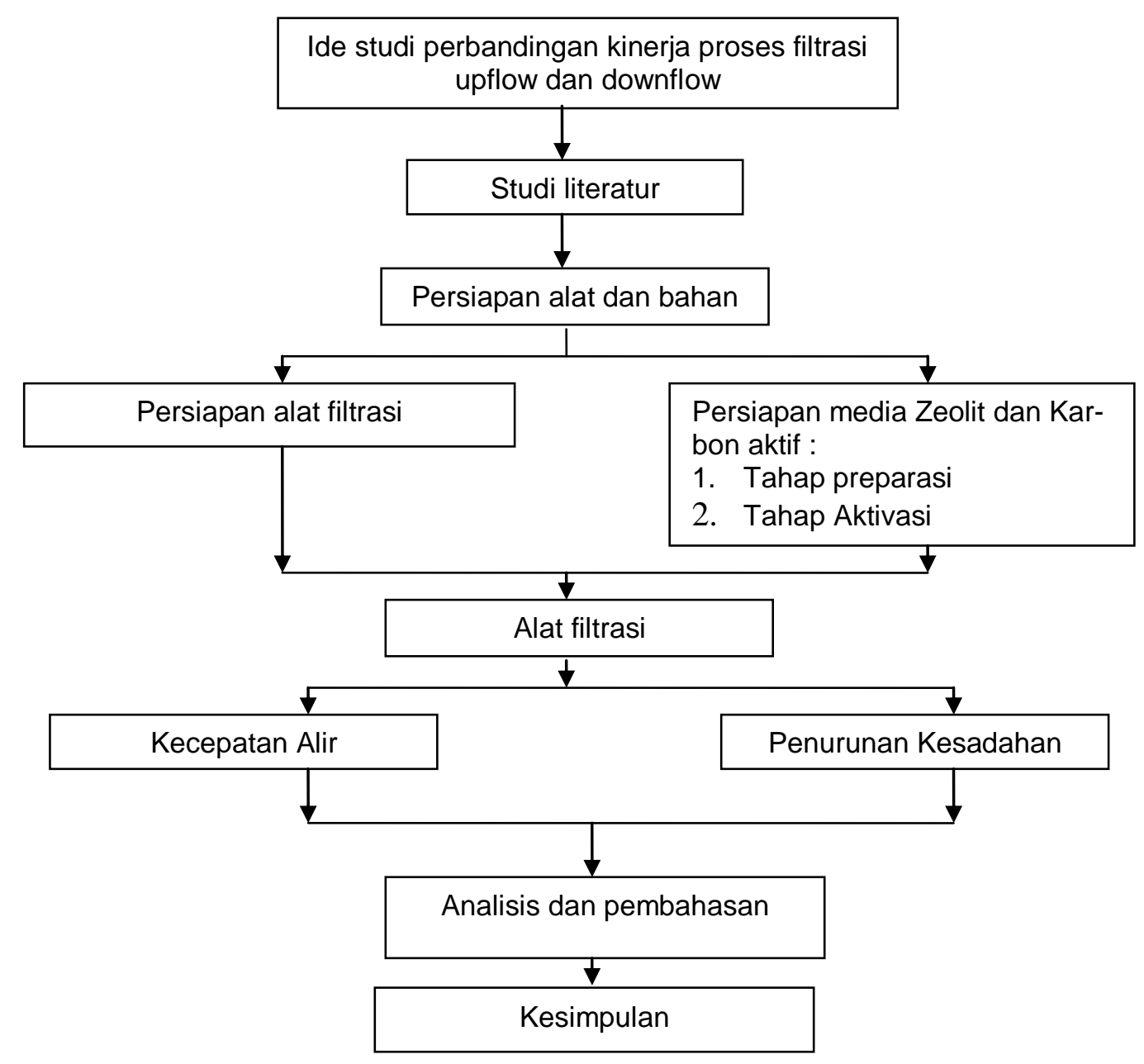

Gambar 6 : Skema rancangan penelitian 
Adapun rancangan penelitiannya dapat dilihat pada gambar 7 di bawah ini :

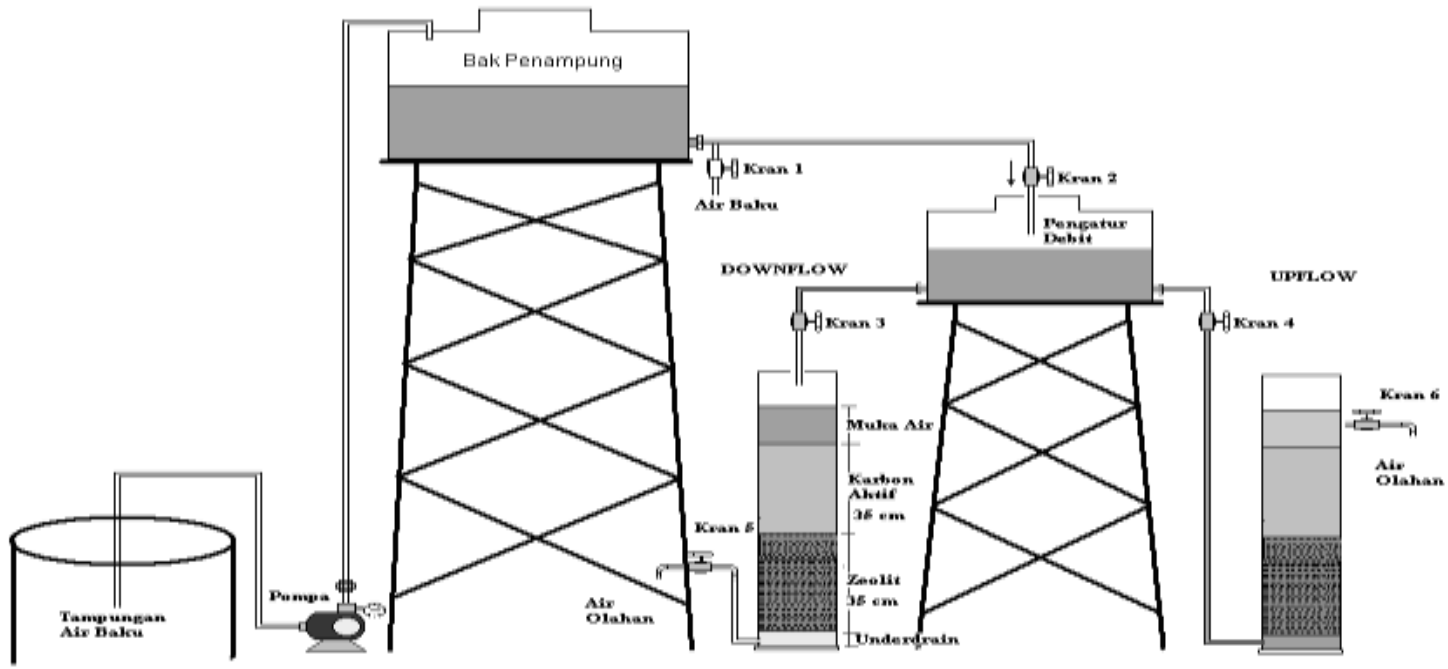

Gambar 7 : Rancangan penelitian

\section{Metode Analisis Data}

Setelah data diperoleh maka langkah selanjutnya adalah mengolah data tersebut. Data yang diperoleh ini merupakan data mentah sehingga harus diolah sesuai dengan tujuan penelitian yang telah dirumuskan untuk mendapatkan kesimpulan. Adapun metode yang digunakan dalam analisis data adalah bentuk grafik dan tabel selanjutnya dilakukan pembahasan dengan jalan membandingkan antar variabel penelitian dan kajian dalam statistik. Statistik yang digunakan dalam penelitian ini adalah statistik uji kilat Tukey.

\section{Penyajian dan Analisis Data Penyajian Data}

Data yang sudah berhasil dikumpulkan melalui kegiatan penelitian ini adalah :

1. Data perbandingan kecepatan alir filtrat antara sistem downflow dan upflow yang dilakukan sebanyak 6 kali pengamatan dalam waktu 6 jam dengan aliran Kontinyu. Adapun data yang di hasilkan dapat dilihat pada tabel 4 sebagai berikut :

Tabel 4. Data perbandingan kecepatan alir antara sistem fitrasi downflow dan upflow

\begin{tabular}{lllllll}
\hline $\begin{array}{l}\text { Waktu } \\
\text { Operasi } \\
\text { (jam) }\end{array}$ & $\begin{array}{l}\text { Filtrat } \\
\text { Upflow } \\
\text { (L/menit) }\end{array}$ & $\begin{array}{l}\text { Filtrat } \\
\text { Downflow } \\
\text { (L/menit) }\end{array}$ & $\begin{array}{l}\text { Penurunan } \\
\text { Upflow } \\
\text { (L/menit) }\end{array}$ & $\begin{array}{l}\text { Penurunan } \\
\text { Downflow } \\
\text { (L/menit) }\end{array}$ & $\begin{array}{l}\text { Penurunan } \\
\text { Upflow } \\
(\%)\end{array}$ & $\begin{array}{l}\text { Penurunan } \\
\text { Downflow } \\
(\%)\end{array}$ \\
\hline 0 & 1 & 1.3 & & & & \\
1 & 1 & 1.3 & 0 & 0 & 0 & 0 \\
2 & 1 & 1.25 & 0 & 0.05 & 0 & 4 \\
3 & 0.99 & 1.18 & 0.01 & 0.12 & 1 & 9 \\
4 & 0.99 & 1.1 & 0.01 & 0.2 & 1 & 15 \\
5 & 0.99 & 0.9 & 0.01 & 0.4 & 1 & 31 \\
6 & 0.985 & 0.7 & 0.015 & 0.6 & 1.5 & 46 \\
\hline
\end{tabular}

Tabel di atas bertujuan untuk mengetahui perubahan kecepatan alir filtrat selama 6 jam pengamatan. Pada operasi filtrasi dengan sistem upflow kecepatan alirnya lebih stabil dibandingkan dengan operasi filtrasi dengan sistem downflow, walaupun dengan sistem ini menghasilkan kecepatan alir awal yang lebih besar.

2. Data hasil uji untuk parameter kesadahan antara sistem up flow dan down flow dapat dilihat pada tabel 5 di bawah ini : 
Tabel 5 Hasil uji parameter kesadahan antara sistem filtrasi downflow dan upflow.

\begin{tabular}{llllll}
\hline $\begin{array}{l}\text { Waktu } \\
\text { Operasi }\end{array}$ & $\begin{array}{l}\text { Kesadahan Air } \\
\text { Baku } \\
\left(\mathrm{mg} / \mathrm{LaCO}_{3}\right)\end{array}$ & $\begin{array}{l}\text { Kesadahan } \\
\text { Filtrat } \\
\text { Downflow } \\
\left(\mathrm{mg} / \mathrm{L} \mathrm{CaCO}_{3}\right)\end{array}$ & $\begin{array}{l}\text { Kesadahan } \\
\text { Filtrat Upflow } \\
\left(\mathrm{mg} / \mathrm{LaCO}_{3}\right)\end{array}$ & $\begin{array}{l}\text { Efisiensi Down } \\
\text { flow ( \%) })\end{array}$ & $\begin{array}{l}\text { Efisiensi } \\
\text { Up flow ( \% })\end{array}$ \\
\hline 1 & 519.7 & 33.271 & 29.303 & 93.60 & 94.36 \\
2 & 519.7 & 33.790 & 27.744 & 93.50 & 94.66 \\
3 & 519.7 & 32.121 & 27.125 & 93.82 & 94.78 \\
4 & 519.7 & 29.003 & 26.685 & 94.42 & 94.87 \\
5 & 519.7 & 27.124 & 25.988 & 94.78 & 95.00 \\
6 & 519.7 & 26.885 & 25.499 & 94.83 & 95.09 \\
Rata - rata & & & & 94.16 & 94.79 \\
\hline
\end{tabular}

Data di atas merupakan data tentang perbandingan penurunan kesadahan antara sistem filtrasi downflow dan upflow. Data ini memberikan informasi bahwa efisiensi penurunan kesadahan untuk sistem downflow sebesar 94,16 \% sedangkan efisiensi penurunan kesadahan untuk sistem upflow sebesar $94,79 \%$.

\section{Analisis data}

Untuk mengetahui perbedaan penurunan kecepatan alir antara sistem filtrasi downflow dan upflow diinterpretasikan melalui tabel dan grafik. Analisis untuk efisiensi penurunan kesadahan selain menggunakan tabel dan grafik digunakan juga pengujian hipotesis dengan metode statistik uji kilat Tukey dengan tingkat kepercayaan $95 \%$ guna menyimpulkan apakah ada beda yang signifikan terhadap data - data yang dihasilkan.

Pada tabel 6 di atas diketahui operasi filtrasi dengan sistem upflow kecepatan alirnya lebih stabil dibandingkan dengan operasi filtrasi dengan sistem downflow. Hal ini diketahui dari penurunan kecepatan alir sistem filtrasi downflow lebih cepat dibandingkan dengan sistem filtrasi upflow. Adapun grafik penurunan kecepatan alirnya dapat dilihat jelas melalui gambar 8 di bawah ini :

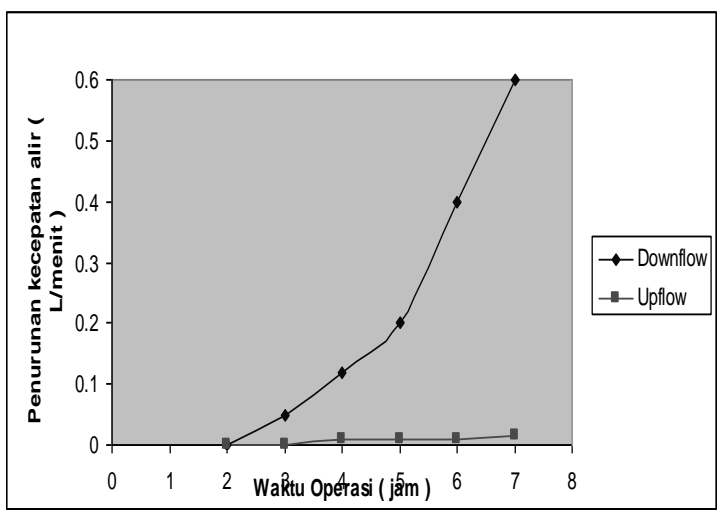

(Gambar 8 : Grafik Penurunan Kecepatan Alir antara System Filtrasi Downflow dan Upflow)
Dari analisis di atas baik melalui tabel 4 maupun gambar 8 dapat disimpulkan bahwa dalam waktu operasi 6 jam filtrasi dengan menggunakan media zeolit dan karbon aktif. Untuk sistem filtrasi upflow kecepatan alirnya stabil sedangkan sistem filtrasi downflow mengalami penurunan sebesar $46 \%$. Dengan demikian dilihat dari penurunan kecepatan alirnya sistem uplow lebih baik daripada downflow.

Dari data tabel 5 di atas diketahui efisiensi penurunan kesadahan dengan sistem filtrasi upflow lebih besar dari pada sistem filtrasi downflow. Sistem filtrasi upflow menghasilkan efisiensi penurunan kesadahan sebesar $94.79 \%$ sedangkan downflow sebesar $94.16 \%$. Jika dianalisis dalam bentuk grafik dapat dilihat pada gambar 9 dan 10 di bawah ini :

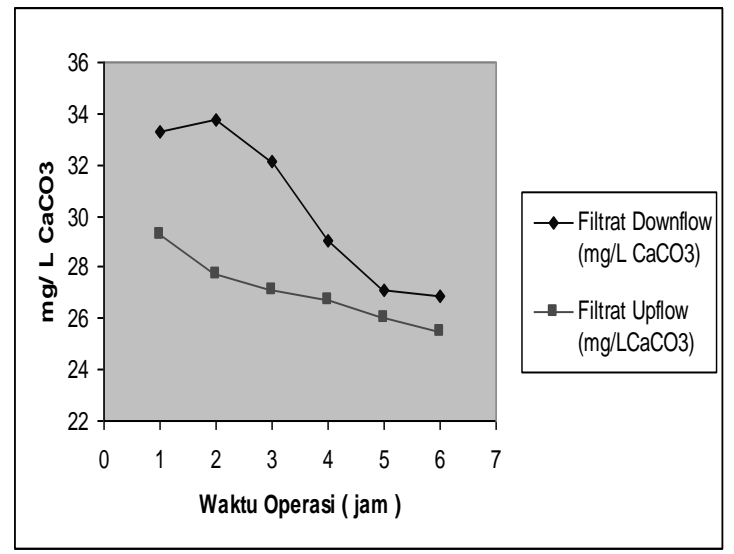

(Gambar 9 : Grafik Kesadahan Filtrat dari System Filtrasi Downflow dan Upflow) 


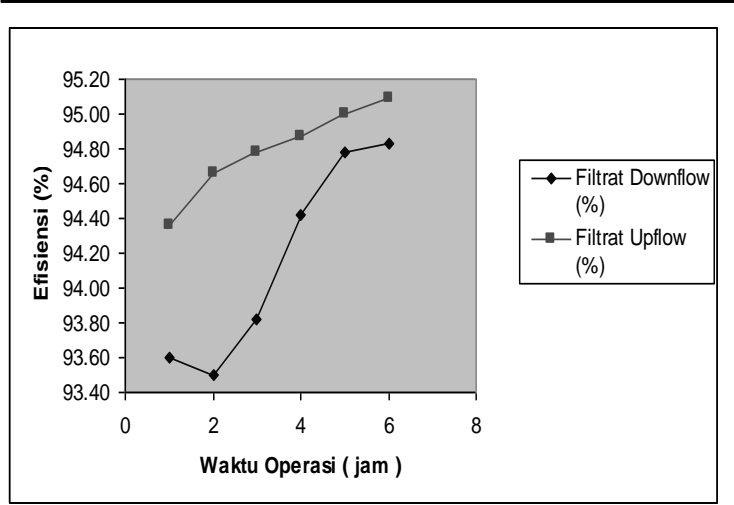

(Gambar 10: Grafik Efisiensi penurunan kesadahan antara sistem Filtrasi Downflow dan Upflow)

Dari Tabel: 5 maupun gambar : 9 dan 10diketahui bahwa hasil filtrasi dari sistem upflow mempunyai nilai kesadahan yang lebih rendah dibandingkan dengan sistem downflow, oleh karena itu penurunan kesadahan untuk sistem upflow mempunyai nilai efisiensi yang lebih tinggi dibandingkan dengan sistem downflow.

Untuk menentukan ada atau tidaknya perbedaan yang signifikan dari data penurunan kesadahan dengan system filtrasi upflow dan downflow pada table : 5 dilakukan uji hipotesis dengan metode statistik uji kilat Tukey dengan tingkat kepercayaan $95 \%$

Tabel 6. Efisiensi Penurunan Kesadahan antara Sistem Filtrasi Upflow dan Downflow

\begin{tabular}{llc}
\hline Waktu Operasi & $\begin{array}{c}\text { Efisiensi } \\
\text { flow (\%) }\end{array}$ & $\begin{array}{c}\text { DownEfisiensi } \\
\text { flow (\%) }\end{array}$ \\
\hline 1 & 93.60 & 94.36 \\
2 & 93.50 & 94.66 \\
3 & 93.82 & 94.78 \\
4 & 94.42 & 94.87 \\
5 & 94.78 & 95.00 \\
6 & 94.83 & 95.09 \\
Rata - Rata & 94.16 & 94.79 \\
\hline
\end{tabular}

Tingkat kepercayaan/ signifikan :

$a=5 \%=0.05$

Jumlah data $: \mathrm{n}=6, \mathrm{~N}-\mathrm{n}=6-6=0$
Daerah kritis :

"Tolak Ho apabila statistik uji $\geq$ table "

Dari data di atas diketahui :

Nilai efisiensi minimal downflow $=93.5$

Nilai efisiensi minimal upflow $=94.36$

Nilai efisiensi maksimal downflow $=94.83$

Nilai efisiensi maksimal donflow $=95.09$

Nilai gabungan yang lebih kecil dari

$$
\begin{aligned}
94.36 & =93.6 \\
& =93.5 \\
& =93.82
\end{aligned}
$$

Jumlah nilai gabungan $=3$

Nilai gabungan yang lebih besar dari

$$
\begin{aligned}
94.83 & =94.87 \\
& =95
\end{aligned}
$$$$
=95.09
$$

Jumlah nilai gabungan $=3$

Jumlah nilai statistik uji $=3+3=6$

Nilai statistik uji dibandingkan dengan table harga - harga kritis statistic uji kilat Tukey ( lampiran 6 ) diketahui :

$\mathrm{a}=5 \%, \mathrm{n}=6, \mathrm{~N}-\mathrm{n}=0$

Nilai table $=7$

Kesimpulan $=$ Karena statistik uji $<$ tabel Maka terima Ho yang berarti "Efisiensi penurunan kesadahan dengan system filtrasi upflow sama dengan system filtrasi downflow".

\section{SIMPULAN}

Berdasarkan hasil penelitian dan pembahasan yang telah dilakukan dapat ditarik kesimpulan sebagai berikut :

1. Pada operasi filtrasi dengan sistem downflow penurunan kecepatan alirnya lebih cepat dibandingkan dengan sistem upflow. Dalam waktu operasi 6 jam filtrasi pengamatan penurunan kecepatan alir sistem filtrasi downflow sebesar $0.6 \mathrm{~L} /$ menit ( $46 \%$ ) sedangkan sistem filtrasi upflow sebesar $0.015 \mathrm{~L} /$ menit ( $1.5 \%$ ).

2. Dari hasil penelitian dengan menggunakan susunan media zeolit : karbon actif setinggi $35 \mathrm{~cm}: 35 \mathrm{~cm}$ menghasilkan efisiensi penurunan kesadahan $94.79 \%$ untuk system filtrasi upflow dan $94.16 \%$ untuk system filtrasi downflow.

\section{DAFTAR PUSTAKA}

Anonymous,2009.SistemPengolahanAir.http://ladawanpiazza.blogspot.com/2009/04/sistempengolahan-air.html ( 24 Januari 2010 ).

Anonymous. Karbon aktif. http://id.wikipedia.org/wiki/karbon aktif ( 27 Januari 2010 ) 
Anonymous. Slow Sand Filter. http://en.wikipedia.org/wiki/slow sand filtration.

( 07 februari 2010 )

Anonymous. Activted carbon. http://en.wikipedia.org/wiki/activated carbon.

(27 Januari 2010 )

Arfandy, Munsir, Teknik Penyediaan Air Bersih untuk Daerah Pedesaan "Skala Prioritas Pemilihan Sumber Air", Makalah dalam Proceeding Kursus Penyediaan Air di Pedesaan, Bandung, 1983.

Atastina S.B, Praswasti P.D.K. Wulan, dan Syarifudin, 2005. Penghilangan Kesadahan Air Yang Mengandung lon $\mathrm{Ca}^{2+}$ Dengan Menggunakan Zeolit Alam Lampung Sebagai Penukar, JURNAL PENELITIAN Fakultas Teknik - UI, depok .hal 1-5

Bapedalda Propinsi Jatim, 2007. Pedoman Pemantauan Kualitas Air Sungai Di Jawa Timur. Surabaya

Bell, R. G., 2001, What are zeolites? URL: http://www.bza.org/zeolites.html.

(27 Januari 2010 )

Collins, M. R. 1998. "Assessing Slow Sand Filtration and Proven Modifications."'In Small Systems Water Treatment Technologies: State of the Art Workshop. NEWWA Joint Regional Operations Conference and Exhibition. Marlborough, Massachusetts.

Gede H Cahyono, 2009. Adsorpsi Karbon Aktif http://gedehace.blogspot.com/2009/03/adsorpsikarbon-aktif.html (27 januari 2010 ).

Hassler, John W.1974. Activated Carbon. Chemical Publishing Co., Inc., NY.

Nusa Idaman said, 1996. Teknologi Pengolahan Air Bersih Dengan Proses Saringan Pair Lambat "Upflow", http://www.kelair.bppt.go.id/Sitpa/Artikel/Pasir/pasir.html . ( 07 Februari 2010 ).

Peraturan menteri kesehatan RI No 416 tahun 1990 tentang persyaratan kualitas airbersih.

Purwoto,Setyo 2007.penyediaan air minum. Surabaya.

Reynold, 1982. the ecology of freshwater phytoplankton.

Robert C. Rice, 1974. Journal (Water Pollution Control Federation), Vol. 46, No. 4, http://www.jstor.org/pss/25038184. (10 juli2010).

Rodhie, S. 2006. Pemanfaatan Zeolit Sebagai Alternatif Pengolahan Limbah Industri. Hal 1-8

SNI-06-6989.12-2004 Tentang Pengujian Kesadahan.

Sugiyono, 2007. Statistika untuk penelitian. Alfabeta, Bandung.

Sutrisno Joko, 2006. Satuan Operasi. UNIPA. Surabaya

Tchobanoglous, Burton FL,1991. Waste water engineering. Mc Graw - Hill Inc.

Zaenal Abidin, 2006. Pengaruh Ketebalan Kombinasi Filter Zeolit dengan Karbon aktif terhadap Penuruna Kesadahan Air Sumur Artesis di Sendangguwo, Tembalang, Kota Semarang. http://digilib.unimus.ac.id/gdl.php?mod=browse\&op=read\&id=itptunimus-gdl-zaenalabid5224\&PHPSESSID=1e67af6fa4bdd962b254ed311c991538. ( 10 juli 2010 ) 